\title{
Pantoea rodasii sp. nov., Pantoea rwandensis sp. nov. and Pantoea wallisii sp. nov., isolated from Eucalyptus
}

\author{
Correspondence \\ Teresa A. Coutinho \\ teresa.coutinho@fabi.up.ac.za
}

\author{
Carrie L. Brady, ${ }^{1}$ Ilse Cleenwerck, ${ }^{2}$ Lorinda van der Westhuizen, ${ }^{3}$ \\ Stephanus N. Venter, ${ }^{3}$ Teresa A. Coutinho ${ }^{3}$ and Paul De Vos ${ }^{2}$
${ }^{1}$ LM-UGent, Laboratory of Microbiology, Faculty of Sciences, Ghent University, Ghent, Belgium
${ }^{2}$ BCCM/LMG Bacteria Collection, Ghent University, Ghent, Belgium
${ }^{3}$ Department of Microbiology and Plant Pathology, Forestry and Agricultural Biotechnology Institute (FABI), University of Pretoria, Pretoria, South Africa

\begin{abstract}
Several Gram-negative-staining, facultatively anaerobic bacterial isolates were obtained from Eucalyptus seedlings showing symptoms of bacterial blight and dieback in Colombia, Rwanda and South Africa. Partial 16S rRNA gene sequencing, together with partial gyrB sequencing, placed the isolates in the genus Pantoea and indicated that they constituted three novel species. Multilocus sequence analysis (MLSA) based on partial sequences of $g y r B, r p o B$, infB and atpD revealed Pantoea dispersa, Pantoea eucrina and Pantoea cypripedii as their closest phylogenetic relatives. DNA-DNA hybridization studies confirmed the classification of the new isolates as three novel species and phenotypic tests allowed them to be differentiated from their closest phylogenetic neighbours. The names Pantoea rodasii sp. nov. [type strain LMG $26273^{\top}=B D 943^{\top}$ (deposited with the Plant Pathogenic and Plant Protecting Bacteria Collection, South Africa) $=\mathrm{BCC} 581^{\top}$ (deposited with the Bacterial Culture Collection, Forestry and Agricultural Institute, South Africa)], Pantoea rwandensis sp. nov. (type strain LMG $26275^{\top}=\mathrm{BD} 944^{\top}=\mathrm{BCC} 571^{\top}$ ) and Pantoea wallisii sp. nov. (type strain LMG $26277^{\top}=B D 946^{\top}=B C C 682^{\top}$ ) are proposed.
\end{abstract}

Pantoea ananatis has been reported as the causal agent of bacterial blight and dieback of Eucalyptus seedlings in South Africa. Young leaves present symptoms first, with leaf spots that become water-soaked and eventually form larger necrotic lesions. Trees either fail to survive or become multi-stemmed (Coutinho et al., 2002). In the last decade, similar symptoms have been observed in nurseries and plantations in Uganda, Argentina and Uruguay. The bacteria isolated from these diseased trees were identified as belonging to three novel species of the genus Pantoea: $P$. vagans, P. eucalypti and P. deleyi (Brady et al., 2009). It has been suggested that a complex of Pantoea species may be responsible for bacterial blight and dieback in Africa and South America (Coutinho et al., 2011). P. ananatis, P. vagans, $P$. eucalypti and $P$. deleyi, have been isolated from a wide range of Eucalyptus species, hybrids and clones which is of concern for the forestry industry.

Abbreviation: MLSA, multilocus sequence analysis.

The GenBank/EMBL/DDBJ accession numbers for the 16S rRNA, atp $D$, gyrB, infB and $r p o B$ gene sequences are JF295053-JF295058, JF295013-JF295022, JF295023-JF295032, JF295033-JF295042 and JF295043-JF295052, respectively.

Two supplementary tables are available with the online version of this paper.
As part of an on-going isolation campaign in countries of Africa, South America and Asia, Eucalyptus seedlings are regularly examined for symptoms of bacterial blight and dieback. Bacterial isolates obtained from the diseased material are identified using a polyphasic approach based on Gram staining, oxidation-fermentation testing, partial $16 \mathrm{~S}$ rRNA gene- and gyrB-sequencing. $P$. ananatis and $P$. eucalypti are regularly isolated in South Africa, while $P$. vagans and $P$. dispersa are more commonly isolated in Colombia and Thailand, respectively (Swart, 2009). In 2006/2007, bacteria were isolated from diseased Eucalyptus material in Colombia, Rwanda and South Africa which could not be assigned to any of the recognized species of the genus Pantoea. Sequencing of the gyrB gene placed these isolates in the genus Pantoea, and indicated that they constituted three novel species (Swart, 2009). In the present study, these isolates were further examined using a polyphasic approach to confirm that they constitute three novel species of the genus Pantoea.

Bacteria were isolated from diseased Eucalyptus material as previously described (Brady et al., 2009). Reference strains were obtained from the BCCM/LMG Bacteria Collection (http://bccm.belspo.be) and recovered on tryptic soy agar according to the provider's instructions. A list of strains 
used in this study is available in Table S1 in IJSEM Online. Genomic DNA was extracted using the alkali method (Niemann et al., 1997) and stored at $-20{ }^{\circ} \mathrm{C}$.

Almost complete 16S rRNA gene sequences (1346 bp) were determined for two strains from each proposed novel species using the primers and conditions as previously described (Coenye et al., 1999). Consensus sequences were aligned using the CLUSTAL W application in BioEdit version 7.0.9.0 (Hall, 1999) and the overhangs were trimmed. Phylogenetic trees were constructed using the maximumparsimony and neighbour-joining methods in MEGA 5.0 (Tamura et al., 2011) and PAUP 4.0b10 (Swofford, 2000), respectively. The reliability of the clusters was evaluated by bootstrap analysis with 1000 replicates. As the topology of the resulting phylogenetic trees was similar, only the maximum-parsimony tree is shown.

In the $16 \mathrm{~S}$ rRNA gene maximum-parsimony tree (Fig. 1), the novel species formed three definite clusters corresponding to the country of isolation, each with $100 \%$ bootstrap support. The isolates from Colombia and Rwanda were more closely related to each other than to the South African isolates and formed a clade on a separate branch, while the South African isolates clustered with $P$. dispersa and P. eucrina. Several 'core' species of the genus Pantoea formed a well-supported clade with the type strain of $P$. agglomerans while the remainder clustered at a lower level. It has been demonstrated previously that the genus Pantoea is polyphyletic (Brady et al., 2010b), making it increasingly difficult to allocate novel species to this genus based solely on 16S rRNA gene sequencing. Numerous genera within the family Enterobacteriaceae are polyphyletic when analysis is based on 16S rRNA gene sequences alone, and whether this gene is an appropriate choice to construct phylogenies of closely related bacterial taxa has been questioned (Naum et al., 2008).

The 16S rRNA gene sequence pairwise similarity obtained was $>99 \%$ amongst the Colombian isolates, $>99.4 \%$ amongst the isolates from Rwanda and $>99.8 \%$ between the South African isolates. The Colombian, Rwandan and South African isolates displayed more than $97.0 \% 16 \mathrm{~S}$ rRNA gene sequence pairwise similarity amongst each other and with various species of the family Enterobacteriaceae. Based on 16S rRNA gene sequencing, the closest phylogenetic relatives of the Colombian and Rwandan isolates were P. septica, P. eucrina, P. dispersa, P. cypripedii, Erwinia aphidicola, Kluyvera intermedia, Buttiauxella agrestis and Enterobacter ludwigii. The isolates from South Africa were most closely related to $P$. dispersa and P. eucrina.

Multilocus Sequence Analysis (MLSA) based on partial sequences of $g y r B, r p o B$, infB and atpD, four proteinencoding genes, was performed on all strains belonging to the three novel species as described previously (Brady et al., 2008). Consensus sequences were aligned using the CLUSTAL $\mathrm{w}$ application in BioEdit version 7.0.9.0 (Hall, 1999) and the overhangs were trimmed. The best-fit evolutionary model was selected by Modeltest 3.7 (Posada \& Crandall,
1998) and maximum-likelihood and neighbour-joining trees were constructed in PHYML (Guindon \& Gascuel, 2003) and PAUP 4.0b10 (Swofford, 2000), respectively, using the parameters determined by Modeltest. Bootstrap analysis with 1000 replicates was performed on each of the trees to gauge the reliability of the clusters. The topology of both trees was similar and therefore only the maximumlikelihood tree is shown.

The peptide sequences were also determined for each gene and a concatenated peptide sequence tree was constructed in PHYML using the parameters described previously (Brady et al., 2008). In the maximum-likelihood tree based on concatenated sequences of the four genes (Fig. 2), the isolates from Colombia, Rwanda and South Africa formed three separate clusters (with $100 \%$ bootstrap values) in the strongly supported clade containing all recognized species of the genus Pantoea. The same topology was observed in the concatenated peptide sequence tree (data not shown) providing support at the protein level for the delineation of these isolates as three novel species of the genus Pantoea. The three novel species were found to share 20 of the 23 atpD signature nucleotides that can be used to differentiate species of the genus Pantoea from closely related species of the genera Tatumella and Erwinia (Brady et al., 2010a). The MLSA data therefore placed the isolates in the genus Pantoea and suggested that they belong to three novel species. As observed in the 16S rRNA gene phylogenetic tree, the isolates from Colombia and Rwanda were more closely related to each other than to those from South Africa. Based on the MLSA data, the closest phylogenetic relatives of the three novel species were $P$. eucrina, $P$. dispersa and P. cypripedii.

Two isolates were selected from each novel species for DNA-DNA hybridization experiments. Isolates from Colombia and Rwanda were hybridized with each other, and a representative isolate from each proposed novel species was hybridized with the type strains of $P$. septica, P. eucrina, P. dispersa, P. cypripedii, Erwinia aphidicola, K. intermedia, B. agrestis and Enterobacter ludwigii. The isolates from South Africa were also hybridized amongst each other, and a representative isolate was hybridized with the type strains of $P$. dispersa, P. eucrina and P. cypripedii. Large-scale DNA extraction was performed on the strains using a modified version (Cleenwerck et al., 2002) of the method described by Wilson (1987). DNA-DNA hybridizations (four replications) were performed at $45{ }^{\circ} \mathrm{C}$ using the microplate method (Ezaki et al., 1989) with some modifications (Cleenwerck et al., 2002). Reciprocal reactions $(\mathrm{A} \times \mathrm{B}$ and $B \times A$ ) were performed for each DNA pair from all strains and their variation was within the limits for this method (Goris et al., 1998). Isolates of the novel species exhibited $>98 \%$ DNA-DNA relatedness when hybridized against each other, but $<44 \%$ DNA-DNA relatedness was observed between the Colombian and Rwandan isolates, and $<35 \%$ between these isolates and the type strains of the other species of the genus. The isolates from South Africa displayed $<40 \%$ DNA-DNA relatedness to $P$. dispersa, $P$. 


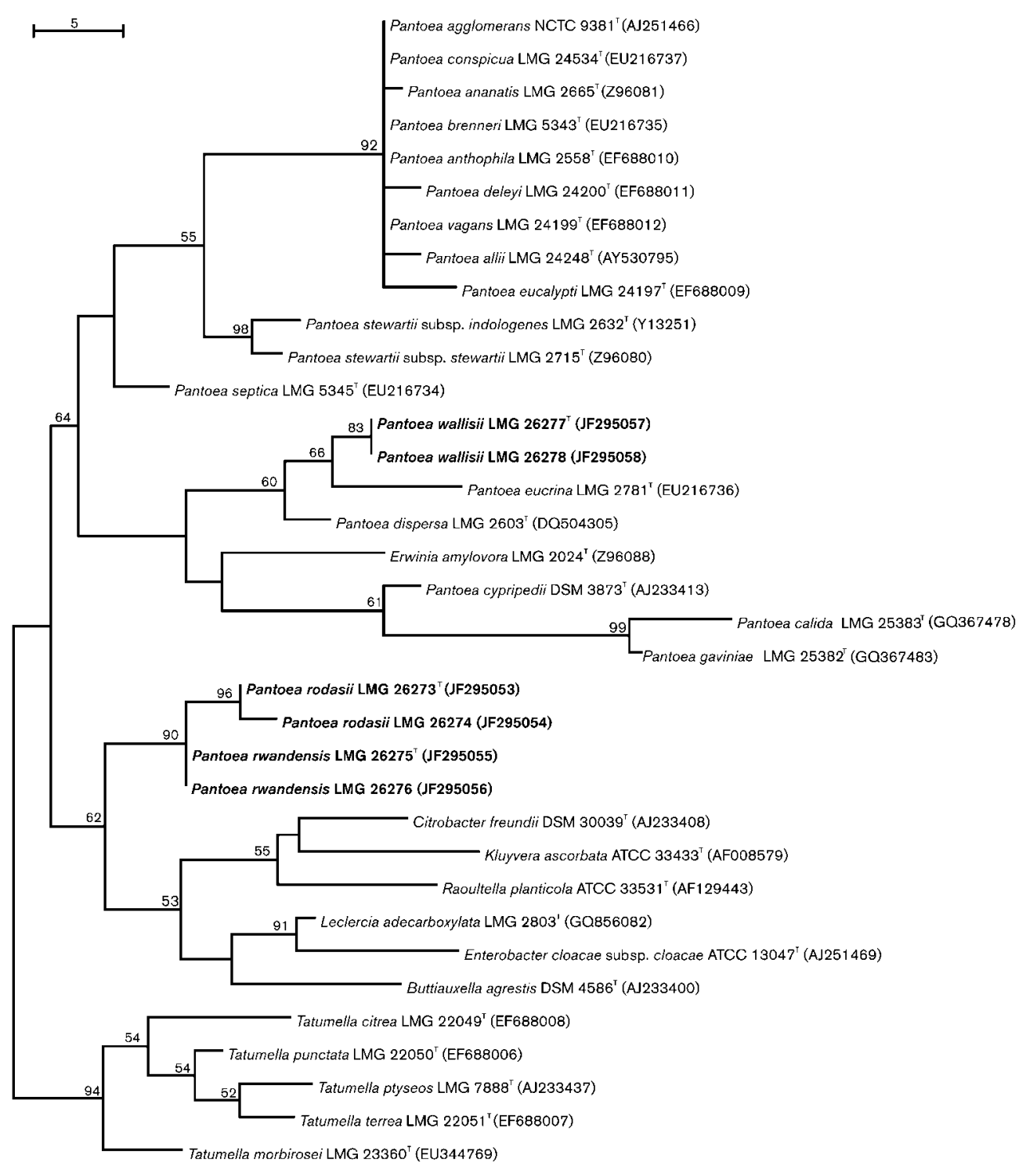

Fig. 1. Maximum-parsimony tree based on almost-complete 16S rRNA gene sequences of members of the genus Pantoea and phylogenetically related species. Bootstrap values after 1000 replicates are expressed as percentages. Species belonging to the genus Tatumella were included as outgroups. Bar, 5 substitutions per site.

eucrina and P. cypripedii, their closest phylogenetic relatives. The hybridization results confirmed that the isolates constituted three novel species and are summarized in Table S2 in IJSEM Online.

The DNA G $+\mathrm{C}$ contents of the novel species was measured by HPLC (Mesbah et al., 1989) and were as follows: LMG $26273^{\mathrm{T}}$ and LMG 26274, 53.2 and $53.0 \mathrm{~mol} \%$; LMG $26275^{\mathrm{T}}$ and LMG 26276, 51.9 and $52.0 \mathrm{~mol} \%$ and LMG $26277^{\mathrm{T}}$ and LMG 26278, 55.5 and $55.6 \mathrm{~mol} \%$. These values fell within the $\mathrm{G}+\mathrm{C}$ content range of the recently emended description of the genus Pantoea (Brady et al., 2010b).
API 20E, API 50CHB/E (bioMérieux) and GN2 MicroPlate (Biolog) tests were performed, according to the manufacturers' instructions, on the isolates from Colombia, Rwanda and South Africa. Cell suspensions were prepared from cultures grown on tryptic soy agar at $28{ }^{\circ} \mathrm{C}$ for $12 \mathrm{~h}$. API and Biolog tests were read after 24 and $48 \mathrm{~h}$ of incubation. Data were compared with those previously published for species of the genus Pantoea (Brady et al., 2009, 2010a, b) and generated under the same conditions. The novel species were found to share all phenotypic traits characteristic of the genus Pantoea (Brady et al., 2010b; Grimont \& Grimont, 2005; Mergaert et al., 1993). The results are listed in the species descriptions below. The 


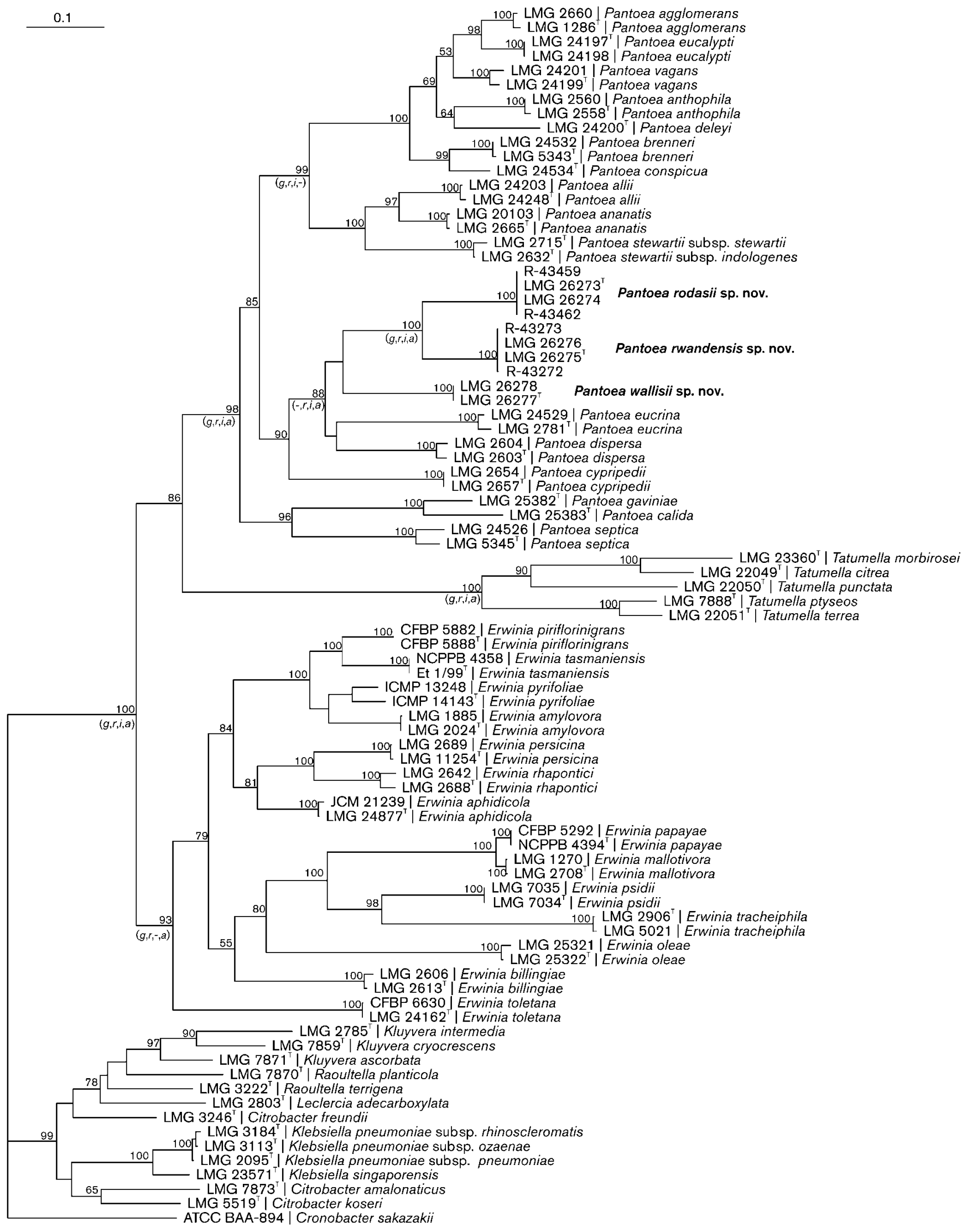


Fig. 2. Maximum-likelihood tree based on concatenated housekeeping gene sequences of strains of the genus Pantoea. Bootstrap values after 1000 replicates are expressed as percentages. Major clades also supported by the single gene phylogenies are indicated by $g(g y r B), r(r p o B), i($ infB) and a $(a t p D)$ in parentheses. Cronobacter sakazakii ATCC BAA-894 was included as an outgroup. Gene sequences for C. sakazakii were obtained from http://www.ncbi.nlm.nih.gov. Bar, 0.1 substitutions per site.

three novel species could be differentiated from each other by their reactions to dulcitol, sucrose, adonitol, fucose, psicose and serine. The most useful characteristics for differentiating the novel species from each other and their closest phylogenetic relatives are listed in Table 1.

The whole-cell fatty acid methyl ester composition was determined for two isolates from each novel species as well as for the type strain of the type species of the genus, $P$. agglomerans, using the Microbial Identification System, Sherlock version 3.10 (MIDI) and the TSBA50 identification library version 5.0 according to the previously published protocol (Mergaert et al., 1993). A gas chromatograph (6890N; Agilent Technologies) was used for separation of the fatty acid methyl esters. Cells were harvested from cultures grown on trypticase soy agar (BBL 11768) for $24 \mathrm{~h}$ at $28{ }^{\circ} \mathrm{C}$. The novel species and P. agglomerans displayed similar fatty acid compositions, corresponding with those available in literature (Mergaert et al., 1993, 1999). The major fatty acids included $\mathrm{C}_{12: 0}, \mathrm{C}_{14: 0}, \mathrm{C}_{16: 0}, \mathrm{C}_{17: 0}$ cyclo, $\mathrm{C}_{18: 1} \omega 7 c$, and summed features 2 (iso- $\mathrm{C}_{16: 1}$ and/or $\mathrm{C}_{14: 0} 3$ $\mathrm{OH})$ and $3\left(\mathrm{C}_{16: 1} \omega 7 c\right.$ and /or iso- $\left.\mathrm{C}_{15: 0} 2-\mathrm{OH}\right)$. The fatty acid profiles for the novel species are presented in the species descriptions below.

Based on the genotypic and phenotypic data generated in this study, it is clear that the isolates from the diseased Eucalyptus seedlings in Colombia, Rwanda and South Africa constitute three novel species in the genus Pantoea. Therefore we propose to classify them as Pantoea rodasii sp. nov. (isolated from Colombia, type strain LMG $26273^{\mathrm{T}}$ $=\mathrm{BD} 943^{\mathrm{T}}$ ), Pantoea rwandensis sp. nov. (isolated from Rwanda, type strain LMG $26275^{\mathrm{T}}=\mathrm{BD} 944^{\mathrm{T}}$ ) and Pantoea wallisii sp. nov. (isolated from South Africa, type strain LMG $26277^{\mathrm{T}}=$ BD $\left.946^{\mathrm{T}}\right)$.

\section{Description of Pantoea rodasii sp. nov.}

Pantoea rodasii (ro.da'si.i. N.L. masc. gen. n. rodasii of Rodas, named after Carlos Rodas for his contribution to forest pathology in Colombia).

Cells are Gram-negative-staining, short rods $(1 \times 1.5-3 \mu \mathrm{m})$ occurring singly or in pairs, weakly motile and non-sporeforming. Colonies are round, smooth and convex with entire margins on tryptone soy agar and light beige in colour after incubation of $24 \mathrm{~h}$ at $28{ }^{\circ} \mathrm{C}$. Facultatively anaerobic, oxidase-negative and catalase-positive. Acetoin and $\beta$-galactosidase are produced, but $\mathrm{H}_{2} \mathrm{~S}$, urease and indole are not produced and citrate is not utilized. Tests for arginine dihydrolase, lysine decarboxylase and ornithine decarboxylase are all negative. Acid is produced from the fermentation of glycerol, L-arabinose, D-ribose, D-xylose, Dadonitol, D-galactose, D-glucose, D-fructose, D-mannose, Lrhamnose, inositol, D-mannitol, $N$-acetylglucosamine, arbutin, aesculin ferric citrate, salicin, cellobiose, melibiose, sucrose, trehalose, gentiobiose, D-fucose and D-arabitol (API $50 \mathrm{CHB} / \mathrm{E})$. The following carbon sources are utilized at $28{ }^{\circ} \mathrm{C}$ by the majority of strains tested including the type strain, after $24 \mathrm{~h}$ incubation: Tweens 40 and $80, \mathrm{~N}$-acetyl-Dglucosamine, adonitol, L-arabinose, D-arabitol, cellobiose, erythritol, D-fructose, D-galactose, gentiobiose, D-glucose, inositol, lactose, D-mannitol, D-mannose, melibiose, methyl $\beta$-D-glucoside, D-psicose, L-rhamnose, D-sorbitol, sucrose, trehalose, pyruvic acid methyl ester, succinic acid monomethyl ester, acetic acid, formic acid, D-galactonic acid lactone, D-galacturonic acid, D-gluconic acid, D-glucosaminic acid, D-glucuronic acid, DL-lactic acid, quinic acid, Dsaccharic acid, succinic acid, bromosuccinic acid, glucuronamide, D-alanine, L-alanine, L-aspargine, L-aspartic acid, L-glutamic acid, glycyl L-aspartic acid, glycyl L-glutamic acid, L-histidine, L-proline, D-serine, L-serine, urocanic acid, inosine, uridine, thymidine, glycerol, DL- $\alpha$-glycerol phosphate, $\alpha$-D-glucose 1-phosphate, D-glucose 6-phosphate (Biolog). Strains display the following fatty acid profile: $\mathrm{C}_{12: 0}(4.5 \%), \mathrm{C}_{14: 0}(6.7 \%), \mathrm{C}_{16: 0}(27.4 \%), \mathrm{C}_{17: 0}$ cyclo $(8.8 \%), \mathrm{C}_{18: 1} \omega 7 c(11.0 \%)$, summed feature 2 (iso- $\mathrm{C}_{16: 1}$ and/or $\left.\mathrm{C}_{14: 0} 3-\mathrm{OH}\right)(13.9 \%)$ and summed feature 3 $\left(\mathrm{C}_{16: 1} \omega 7 c\right.$ and /or iso- $\left.\mathrm{C}_{15: 0} 2-\mathrm{OH}\right)(23.8 \%)$.

The type strain is LMG $26273^{\mathrm{T}}$ [= BD $943^{\mathrm{T}}$ (deposited with the Plant Pathogenic and Plant Protecting Bacteria Collection, South Africa) $=$ BCC $581^{\mathrm{T}}$ (deposited with the Bacterial Culture Collection, Forestry and Agricultural Biotechnology Institute, South Africa)]. The DNA G +C content of the type strain is $53.2 \mathrm{~mol} \%$. Strains belonging to this species were isolated from lesions on Eucalyptus leaves exhibiting symptoms of bacterial blight and dieback in Colombia.

\section{Description of Pantoea rwandensis sp. nov.}

Pantoea rwandensis (rwan.den'sis. N.L. fem. adj. rwandensis of or belonging to Rwanda, referring to the country of isolation).

Cells are Gram-negative-staining, short rods $(1 \times 2-3 \mu \mathrm{m})$ occurring singly or in pairs, non-motile and non-sporeforming. Colonies are round, smooth and convex with entire margins on tryptone soy agar and beige in colour after incubation of $24 \mathrm{~h}$ at $28{ }^{\circ} \mathrm{C}$. Facultatively anaerobic, oxidase-negative and catalase-positive. $\beta$-Galactosidase is produced, but $\mathrm{H}_{2} \mathrm{~S}$, urease and indole are not produced 
Table 1. Phenotypic characteristics differentiating the novel species from each other, from the type species of the genus Pantoea and other species of the genus associated with bacterial blight and dieback of Eucalyptus

Species: 1 , Pantoea rodasii sp. nov. ( $n=4) ; 2$, Pantoea rwandensis sp. nov. $(n=4) ; 3$, Pantoea wallisii sp. nov. $(n=5) ; 4, P$. agglomerans; 5 , $P$. ananatis; 6, P. deleyi; 7, P. dispersa; 8, P. eucalypti; 9, P. eucrina; 10, P. septica; 11, P. vagans; 12 , P. cypripedii; 13 , P. gaviniae; 14, P. calida. $n$, Number of strains tested; +, 90-100\% strains positive in 1-2 days; $(+$ ), 90-100\% strains positive in 1-4 days; - , negative; d, $11-89 \%$ strains positive in $1-4$ days; (d), 11-89\% strains positive in 3-4 days; ND, not determined. Data were taken from the following sources: taxa 1, 2, 3 (this study), taxa 4-12 (Brady et al., 2009, 2010a, b; Grimont \& Grimont, 2005), taxa 13, 14 (Popp et al., 2010). Only data generated under the same conditions are listed.

\begin{tabular}{|c|c|c|c|c|c|c|c|c|c|c|c|c|c|c|}
\hline Characteristic & 1 & 2 & 3 & 4 & 5 & 6 & 7 & 8 & 9 & 10 & 11 & 12 & 13 & 14 \\
\hline \multicolumn{15}{|l|}{ Acid from: } \\
\hline Glycerol & + & + & + & (d) & + & + & (d) & $\mathrm{d}$ & - & $\mathrm{d}$ & $\mathrm{d}$ & + & + & + \\
\hline Dulcitol & - & + & + & - & - & - & - & - & - & - & - & - & - & - \\
\hline Lactose & - & - & - & $\mathrm{d}$ & + & - & + & $(+)$ & $\mathrm{d}$ & $\mathrm{d}$ & $(+)$ & - & + & + \\
\hline Sucrose & + & - & - & + & + & + & + & + & + & $\mathrm{d}$ & + & + & + & ND \\
\hline Raffinose & - & - & - & (d) & + & - & - & - & - & - & - & - & + & ND \\
\hline \multicolumn{15}{|l|}{ Utilization of: } \\
\hline Adonitol & + & - & - & - & - & - & - & - & + & - & - & - & - & - \\
\hline$i$-Erythritol & + & + & - & - & - & - & + & - & $\mathrm{d}$ & - & - & - & - & - \\
\hline L-Fucose & - & + & + & - & - & - & - & - & - & $\mathrm{d}$ & - & - & - & - \\
\hline Lactose & $\mathrm{d}$ & - & - & - & + & - & - & + & - & $\mathrm{d}$ & - & + & + & + \\
\hline Lactulose & - & - & - & - & + & - & - & - & - & d & - & - & + & + \\
\hline Melibiose & $\mathrm{d}$ & + & - & - & + & - & - & - & - & $\mathrm{d}$ & - & + & + & + \\
\hline D-Psicose & + & + & - & + & + & + & (d) & (d) & $\mathrm{ND}$ & $\mathrm{ND}$ & - & + & $\mathrm{ND}$ & ND \\
\hline Sucrose & + & - & - & $(+)$ & + & + & + & + & + & $\mathrm{d}$ & + & + & + & + \\
\hline Xylitol & - & - & - & - & - & - & - & - & + & $\mathrm{d}$ & - & - & - & - \\
\hline Quinic acid & + & + & $\mathrm{d}$ & - & $(+)$ & - & - & - & - & - & - & + & - & - \\
\hline D-Serine & $\mathrm{d}$ & $\mathrm{d}$ & - & - & - & - & - & - & ND & ND & - & $(+)$ & ND & ND \\
\hline
\end{tabular}

and citrate is not utilized. Negative results in tests for arginine dihydrolase, lysine decarboxylase and ornithine decarboxylase. Acid is produced from the fermentation of glycerol, D-arabinose, L-arabinose, D-ribose, D-xylose, Dgalactose, D-glucose, D-fructose, D-mannose, L-rhamnose, dulcitol, inositol, D-mannitol, $\mathrm{N}$-acetylglucosamine, arbutin, aesculin ferric citrate, salicin, cellobiose, melibiose, trehalose, gentiobiose, D-fucose, L-fucose and D-arabitol (API 50CHB/E). The following carbon sources are utilized at $28{ }^{\circ} \mathrm{C}$ by the majority of strains tested including the type strain, after $24 \mathrm{~h}$ incubation: Tweens 40 and $80, \mathrm{~N}$-acetyl-Dglucosamine, L-arabinose, D-arabitol, cellobiose, erythritol, D-fructose, L-fucose, D-galactose, gentiobiose, D-glucose, inositol, D-mannitol, D-mannose, melibiose, methyl $\beta$-Dglucoside, D-psicose, L-rhamnose, trehalose, pyruvic acid methyl ester, succinic acid monomethyl ester, acetic acid, formic acid, D-galactonic acid lactone, D-galacturonic acid, D-gluconic acid, D-glucosaminic acid, D-glucuronic acid, DLlactic acid, quinic acid, D-saccharic acid, succinic acid, bromosuccinic acid, glucuronamide, L-alanine, L-alanyl glycine, L-aspargine, L-aspartic acid, L-glutamic acid, glycyl L-aspartic acid, glycyl L-glutamic acid, L-proline, D-serine, Lserine, inosine, uridine, thymidine, glycerol, DL- $\alpha$-glycerol phosphate, $\alpha$-D-glucose 1-phosphate, D-glucose 6-phosphate (Biolog). Strains display the following fatty acid profile: $\mathrm{C}_{12: 0}(4.2 \%), \mathrm{C}_{14: 0}(6.9 \%), \mathrm{C}_{16: 0}(26.1 \%), \mathrm{C}_{17: 0}$ cyclo $(7.1 \%), \mathrm{C}_{18: 1} \omega 7 c(11.8 \%)$, summed feature 2 (iso- $\mathrm{C}_{16: 1}$ and/or $\left.\mathrm{C}_{14: 0} 3-\mathrm{OH}\right)(14.3 \%)$ and summed feature 3 $\left(\mathrm{C}_{16: 1} \omega 7 c\right.$ and/or iso- $\left.\mathrm{C}_{15: 0} 2-\mathrm{OH}\right)(26.5 \%)$.
The type strain is LMG $26275^{\mathrm{T}}$ [= BD $944^{\mathrm{T}}$ (deposited with the Plant Pathogenic and Plant Protecting Bacteria Collection, South Africa) $=$ BCC $571^{\mathrm{T}}$ (deposited with the Bacterial Culture Collection, Forestry and Agricultural Biotechnology Institute, South Africa)]. The DNA G + C content of the type strain is $51.2 \mathrm{~mol} \%$. Strains belonging to this species were isolated from lesions on Eucalyptus leaves exhibiting symptoms of bacterial blight and dieback in Rwanda.

\section{Description of Pantoea wallisii sp. nov.}

Pantoea wallisii (wal.li'si.i. N.L. masc. gen. n. wallisii of Wallis, named after F. M. Wallis for his contribution to the field of phytobacteriology in South Africa).

Cells are Gram-negative-staining, short rods $(1 \times 1-2.5 \mu \mathrm{m})$ occurring singly or in pairs, motile and non-spore-forming. Colonies are round, smooth and convex with entire margins on tryptone soy agar and pale yellow in colour after incubation of $24 \mathrm{~h}$ at $28{ }^{\circ} \mathrm{C}$. Facultatively anaerobic, oxidase-negative and catalase-positive. $\beta$-Galactosidase is produced, but $\mathrm{H}_{2} \mathrm{~S}$, urease and indole are not produced and citrate is utilized. Negative result in tests for arginine dihydrolase, lysine decarboxylase and ornithine decarboxylase. Acid is produced from the fermentation of glycerol, D-arabinose, L-arabinose, D-ribose, D-xylose, D-galactose, D-glucose, D-fructose, D-mannose, Lrhamnose, dulcitol, inositol, D-mannitol, $N$-acetylglucosamine, arbutin, salicin, cellobiose, maltose, melibiose, trehalose, 
gentiobiose, D-lyxose, D-fucose, L-fucose and D-arabitol (API $50 \mathrm{CHB} / \mathrm{E}$ ). The following carbon sources are utilized at $28{ }^{\circ} \mathrm{C}$ by the majority of strains tested including the type strain, after $24 \mathrm{~h}$ incubation: dextrin, Tweens 40 and $80, \mathrm{~N}$-acetylD-glucosamine, L-arabinose, D-arabitol, cellobiose, D-fructose, L-fucose, D-galactose, gentiobiose, D-glucose, inositol, maltose, D-mannitol, D-mannose, methyl $\beta$-D-glucoside, Lrhamnose, trehalose, pyruvic acid methyl ester, succinic acid monomethyl ester, acetic acid, cis-aconitic acid, citric acid, formic acid, D-galactonic acid lactone, D-galacturonic acid, D-gluconic acid, D-glucosaminic acid, D-glucuronic acid, DLlactic acid, quinic acid, D-saccharic acid, succinic acid, bromosuccinic acid, glucuronamide, D-alanine, L-alanine, Lalanyl glycine, L-aspargine, L-aspartic acid, L-glutamic acid, glycyl L-aspartic acid, glycyl L-glutamic acid, L-serine, inosine, uridine, thymidine, glycerol, DL- $\alpha$-glycerol phosphate, $\alpha$-D-glucose 1-phosphate, D-glucose 6-phosphate (Biolog). Strains display the following fatty acid profile: $\mathrm{C}_{12: 0}(4.2 \%), \mathrm{C}_{14: 0}(6.9 \%), \mathrm{C}_{16: 0}(26.1 \%), \mathrm{C}_{17: 0}$ cyclo $(7.1 \%), \mathrm{C}_{18: 1} \omega 7 c(11.8 \%)$, summed feature 2 (iso- $\mathrm{C}_{16: 1}$ and/or $\left.\mathrm{C}_{14: 0} 3-\mathrm{OH}\right)(14.3 \%)$ and summed feature 3 $\left(\mathrm{C}_{16: 1} \omega 7 c\right.$ and /or iso- $\left.\mathrm{C}_{15: 0} 2-\mathrm{OH}\right)(26.5 \%)$.

The type strain is LMG $26277^{\mathrm{T}}$ [=BD $946^{\mathrm{T}}$ (deposited with the Plant Pathogenic and Plant Protecting Bacteria Collection, South Africa) $=$ BCC $682^{\mathrm{T}}$ (deposited with the Bacterial Culture Collection, Forestry and Agricultural Biotechnology Institute, South Africa)]. The DNA G +C content of the type strain is $55.5 \mathrm{~mol} \%$. Strains belonging to this species were isolated from lesions on Eucalyptus leaves exhibiting symptoms of bacterial blight and dieback in South Africa.

\section{Acknowledgements}

The authors wish to acknowledge Katrien Engelbeen and Fati Thobjane for technical assistance, and Professor J. J. van der Walt and Dr J. P. Euzéby for assistance with the etymology of the species names. We also thank Mike Wingfield and Pieter de Maayer for collecting Eucalyptus material and Emma Steenkamp for discussions relating to the phylogenetic analyses. The BCCM/LMG Bacteria Collection is supported by the Federal Public Planning Service Science Policy, Belgium. C. Brady is the beneficiary of a fellowship granted by the Federal Science Policy Office, Belgium.

\section{References}

Brady, C. L., Cleenwerck, I., Venter, S. N., Vancanneyt, M., Swings, J. \& Coutinho, T. A. (2008). Phylogeny and identification of Pantoea species associated with plants, humans and the natural environment based on multilocus sequence analysis (MLSA). Syst Appl Microbiol 31, 447-460.

Brady, C. L., Venter, S. N., Cleenwerck, I., Engelbeen, K., Vancanneyt, M., Swings, J. \& Coutinho, T. A. (2009). Pantoea vagans sp. nov., Pantoea eucalypti sp. nov., Pantoea deleyi sp. nov. and Pantoea anthophila sp. nov. Int J Syst Evol Microbiol 59, 2339-2345.

Brady, C. L., Venter, S. N., Cleenwerck, I., Vandemeulebroecke, K., De Vos, P. \& Coutinho, T. A. (2010a). Transfer of Pantoea citrea, Pantoea punctata and Pantoea terrea to the genus Tatumella emend. as Tatumella citrea comb. nov., Tatumella punctata comb. nov. and
Tatumella terrea comb. nov. and description of Tatumella morbirosei sp. nov. Int J Syst Evol Microbiol 60, 484-494.

Brady, C. L., Cleenwerck, I., Venter, S. N., Engelbeen, K., De Vos, P. \& Coutinho, T. A. (2010b). Emended description of the genus Pantoea, description of four species from human clinical samples, Pantoea septica sp. nov., Pantoea eucrina sp. nov., Pantoea brenneri sp. nov. and Pantoea conspicua sp. nov., and transfer of Pectobacterium cypripedii (Hori 1911) Brenner et al. 1973 emend. Hauben et al. 1998 to the genus as Pantoea cypripedii comb. nov. Int J Syst Evol Microbiol 60, 2430-2440.

Cleenwerck, I., Vandemeulebroecke, K., Janssens, D. \& Swings, J. (2002). Re-examination of the genus Acetobacter, with descriptions of Acetobacter cerevisiae sp. nov. and Acetobacter malorum sp. nov. Int $J$ Syst Evol Microbiol 52, 1551-1558.

Coenye, T., Falsen, E., Vancanneyt, M., Hoste, B., Govan, J. R. W., Kersters, K. \& Vandamme, P. (1999). Classification of Alcaligenes faecalis-like isolates from the environment and human clinical samples as Ralstonia gilardii sp. nov. Int J Syst Bacteriol 49, 405-413.

Coutinho, T. A., Preisig, O., Mergaert, J., Cnockaert, M. C., Riedel, K. H., Swings, J. \& Wingfield, M. J. (2002). Bacterial blight and dieback of Eucalyptus species, hybrids, and clones in South Africa. Plant Dis 86, $20-25$.

Coutinho, T. A., Venter, S. N., Roux, J, Zhou, X. D. \& Wingfield, M. J. (2011). Bacterial diseases of Eucalyptus. Proceedings of the ACPP APPS 2011 Congress, Darwin, Australia 27-29 April 2011.

Ezaki, T., Hashimoto, Y. \& Yabuuchi, E. (1989). Fluorometric deoxyribonucleic acid-deoxyribonucleic acid hybridization in microdilution wells as an alternative to membrane filter hybridization in which radioisotopes are used to determine genetic relatedness among bacterial strains. Int J Syst Bacteriol 39, 224-229.

Goris, J., Suzuki, K.-I., De Vos, P., Nakase, T. \& Kersters, K. (1998). Evaluation of a microplate DNA-DNA hybridization method compared with the initial renaturation method. Can J Microbiol 44, 1148-1153.

Grimont, P. A. D. \& Grimont, F. (2005). Genus: Pantoea. In Bergey's Manual of Systematic Bacteriology, Volume Two, The Proteobacteria, Part B, The Gammaproteobacteria, 2nd edn, pp. 713-720. Edited by D. J. Brenner, N. R. Krieg \& J. T. Staley. New York: Springer.

Guindon, S. \& Gascuel, O. (2003). A simple, fast, and accurate algorithm to estimate large phylogenies by maximum likelihood. Syst Biol 52, 696-704.

Hall, T. A. (1999). BioEdit: a user-friendly biological sequence alignment editor and analysis program for Windows 95/98/NT. Nucleic Acids Symp Ser 41, 95-98.

Mergaert, J., Verdonck, L. \& Kersters, K. (1993). Transfer of Erwinia ananas (synonym, Erwinia uredovora) and Erwinia stewartii to the genus Pantoea emend. as Pantoea ananas (Serrano 1928) comb. nov. and Pantoea stewartii (Smith 1898) comb. nov., respectively, and description of Pantoea stewartii subsp. indologenes subsp. nov. Int J Syst Bacteriol 43, 162-173.

Mergaert, J., Hauben, L., Cnockaert, M. C. \& Swings, J. (1999). Reclassification of non-pigmented Erwinia herbicola strains from trees as Erwinia billingiae sp. nov. Int J Syst Bacteriol 49, 377-383.

Mesbah, M., Premachandran, U. \& Whitman, W. B. (1989). Precise measurement of the $\mathrm{G}+\mathrm{C}$ content of deoxyribonucleic acid by high-performance liquid chromatography. Int J Syst Bacteriol 39, 159-167.

Naum, M., Brown, E. W. \& Mason-Gamer, R. J. (2008). Is $16 S$ rDNA a reliable phylogenetic marker to characterize relationships below the family level in the Enterobacteriaceae? J Mol Evol 66, 630-642.

Niemann, S., Pühler, A., Tichy, H.-V., Simon, R. \& Selbitschka, W. (1997). Evaluation of the resolving power of three different DNA 
fingerprinting methods to discriminate among isolates of a natural Rhizobium meliloti population. J Appl Microbiol 82, 477-484.

Popp, A., Cleenwerck, I., Iversen, C., De Vos, P. \& Stephan, R. (2010). Pantoea gaviniae sp. nov. and Pantoea calida sp. nov., isolated from infant formula and an infant formula production environment. Int J Syst Evol Microbiol 60, 2786-2792.

Posada, D. \& Crandall, K. A. (1998). MODELTEST: testing the model of DNA substitution. Bioinformatics 14, 817-818.

Swart, L. (2009). Pantoea and Xanthomonas species associated with bacterial blight and die-back of Eucalyptus. MSc thesis. University of Pretoria, Pretoria, South Africa.
Swofford, D. L. (2000). PAUP*: Phylogenetic analysis using parsimony (and other methods) Version 4.0. Sunderland, MA: Sinauer Associates.

Tamura, K., Peterson, D., Peterson, N., Stecher, G., Nei, M. \& Kumar, S. (2011). MEGA5: Molecular evolutionary genetics analysis using maximum likelihood, evolutionary distance, and maximum parsimony methods. Mol Biol Evol 28, 2731-2739.

Wilson, K. (1987). Preparation of genomic DNA from bacteria. In Current Protocols in Molecular Biology, pp. 2.4.1-2.4.5. Edited by F. M. Ausubel, R. Brent, R. E. Kingston, D. D. Moore, J. G. Seidman, J. A. Smith \& K. Struhl. New York: Green Publishing \& Wiley-Interscience. 